of Venus in 1769. He was elected a fellow of the Royal Society in 1772, and spent five months in the Low Countries in survey work. Five years later he made his home at Frampton, Glamorgan, where he equipped a private observatory with a transit instrument by Sisson, a 6-ft. achromatic telescope by Dollond, and other instruments. He lived in the heyday of the professional instrument maker, and such men as Bird, Peter Dollond and Sisson figure among his correspondents in this collection. Distinguished members of the Paris Academy of Sciences, of which he was elected a corresponding member in 1776, also corresponded with him, and the collection includes letters from Lacaille, Messier, Le Monnier and others. Among English astronomers whose letters to Pigott are preserved, Maskelyne and Hornsby are perhaps best known. At present, of course, the question of printing the collection cannot be contemplated; but the Royal Astronomical Society intends to preserve the correspondence carefully until such time as a selection, at least, of the letters can be published.

\section{Earthquakes Recorded during July and August}

BETWEEN July 4 and 31 inclusive thirteen strong earthquakes were registered at $\mathrm{Kew}$, the strongest being apparently on July 29. This came from an epicentre $6,770 \mathrm{~km}$. distant bearing an azimuth $270^{\circ}$ from $K_{\theta}$, and attaining at $K_{e w}$ an amplitude of $870 \mu$. Other strong shocks were on July 11, registered at $02 \mathrm{~h} .30 \mathrm{~m}$. $14 \mathrm{~s}$. U.T. with maximum amplitude $45 \mu$ from $17,700 \mathrm{~km}$., and on July 23 registered at 15h. 07m. 28s. ए.T. with maximum amplitude $87 \mu$ from $12,200 \mathrm{~km}$. At Wellington, Now Zealand, earthquakes registered on July 11 at $c a .02 \mathrm{~h} .12 \mathrm{~m} .37 \mathrm{~s}$. from an epicentre at lat. $33^{\circ} \mathrm{S}$. long. $177^{\circ} \mathrm{W}$., and on July 23 at $15 \mathrm{~h} .03 \mathrm{~m}$. $45 \mathrm{~s}$. from an epicentre distant ca. $66^{\circ}$. During July in New Zealand there were nine locally felt earthquakes, the greatest being on July 10 in upper Takaka with Mercalli scale strength IV, on July 23 at Masterton with Mercalli scale strength III, and on July 28 from Christchurch to Timaru with Mercalli scale strength III.

In August there were five strong earthquakes recorded at $\mathrm{Kew}$ and twenty at Toledo. Those in common were August 2, Kew 01h. $06 \mathrm{~m}$. 39s., Toledo 0lh. $06 \mathrm{~m}$. 38s., distanee from Kew $19,000 \mathrm{~km}$. and from Toledo 19,300 km.; August 10, Kew 15h. 24m. 48s., distance 8,100 km.; Aug. 12, Kew 05h. 03m. 14s., Toledo 05h. 04m. 06s., distance from Kew $9,300 \mathrm{~km}$. and from Toledo 11,180 km.; and August 13, Kew 07h. $47 \mathrm{~m}$. 05s., Toledo 07h. 45m. 29s., distance from Kow $6,200 \mathrm{~km}$. and from Toledo $5,100 \mathrm{~km}$. The United States Coast and Geodetic Survey has determined the epicentre of an earthquake on August 3l, this being lat. $13 \frac{1}{2}^{\circ} \mathrm{N}$. long. $91 \frac{1}{2}^{\circ}$ W., which is in the Pacific Ocean just off the south-west coast of Guatemala in Central America. Time at origin was $16 \mathrm{~h} .10 \cdot 5 \mathrm{~m}$.

\section{The Night Sky in December}

Futl moon occurs on Dec. 11d. 16h. 24m. ס.T., and new moon on Dec. 27d. 15h. 23m. The following conjunctions with the moon take place: Dec. Ild. 00h., Mars $7^{\circ}$ N.; Dec. 12d. 0lh., Saturn $2^{\circ}$ N. ; Dec. 17d. 07h., Jupiter $0.8^{\circ}$ S. ; Dec. 23d. 19h., Venus $3^{\circ} \mathrm{S}$.; Dec. 18d. 13h., Mercury $2^{\circ} \mathrm{S}$. The following occultations of stars brighter than magnitude 6 take place: Dec. 4 d. $18 \mathrm{~h} .09 \cdot 5 \mathrm{~m} ., \psi$ Aqr. $(D)$;
Dec. 13d. 00h. 51.4m., v Gem. (D); Dec. 13d. 02h. 05.3m., v Gem. $(R)$; Dec. 24d. 06h. 19.2m., $\gamma$ Lib. (D). The times refer to Greenwich and $D$ and $R$ refer to disappearance and reappearance respectively. Mercury sets 20 minutes after the sun at the beginning of the month, and about an hour later than the sun in the middle of the month. It attains its greatest easterly elongation on Dec. 23 and on Dec. 30 is stationary. At the end of the month Mercury sets at $17 \mathrm{~h} .15 \mathrm{~m}$. Venus, a morning star, rises at $3 \mathrm{~h} .22 \mathrm{~m}$., $3 \mathrm{~h} .53 \mathrm{~m}$. and $4 \mathrm{~h} .34 \mathrm{~m}$. at the beginning, middle and end of the month respectively. Mars, in the constellation of Taurus, can be seen through most of the night, rising early in the evening and setting in the morning at $8 \mathrm{~h} .36 \mathrm{~m} ., 7 \mathrm{~h} .11 \mathrm{~m}$. and $5 \mathrm{~h} .49 \mathrm{~m}$. at the beginning, middle and end of the month. The planet is in opposition on Dec. 5. Jupiter, in the constellation of Leo, can be seen late at night, rising at $22 \mathrm{~h}$. $11 \mathrm{~m}$., $21 \mathrm{~h}$. $17 \mathrm{~m}$., and $20 \mathrm{~h} .12 \mathrm{~m}$. at the beginning, middle and end of the month respectively. Saturn is near Mars but sets later in the morning. In addition to the above phenomena, Jupiter will be occulted by the moon on Dec. 17d. 07h. 18.6m., reappearing at $8 \mathrm{~h} .14 \cdot 9 \mathrm{~m}$. Winter solstice commences on Dec. 22d. 17h. The Geminid meteors are active during Dec. 1-12, emanating from different radiants in the constellation of Geminus.

\section{Announcements}

Lieut.-Colonel Edgar Pam, consulting engineer to, and deputy delegate director of, the Mond Nickel Company, Ltd., has been elected president of the Institution of Mining and Metallurgy for the session 1944-45.

THE Institution of Mechanical Engineers announces that, thanks to arrangements made by the War Organisation of the British Red Cross and the Order of St. John of Jerusalem, 37 candidates recently sat for the Institution's examinations in prisoner. of-war camps in Germany. No fewer than 34 (92 per cent) passed with an exceptionally high average percentage marking. The results reflect credit toth on the candidates and on members of the Institution and others in the camps who organized classes and acted as instructors.

THE following appointments have been made in the Colonial Service: D. J. Cowan to be agricultural officer, Uganda; A. Storrar to be agricultural officer, Kenya; T. P. Weldon to be agricultural officer, Sierra Leone; M. J. Fitzpatrick to be veterinary research officer, Kenya ; G. Q. Fowler to be veterinary officer, Nyasaland; P. D. L. Guilbride to be veterin. ary officer, Northern Rhodesia; G. W. G. Briggs (agricultural officer, Nigeria) to be senior agricultural officer, Nigeria ; J. W. Wallace (agricultural officer, Nigeria) to be senior agricultural officer, Nigeria; F. S. Collier (senior assistant conservator of forests, Nigeria) to be conservator of forests, Nigeria.

Dr. J. D. Rolleston writes: Dr. John Fulton has directed my attention to an error in my obituary of Dr. A. C. Klebs in NatuRE of September 4, p. 269. The bibliography of Harvey Cushing was prepared by the Harvey Cushing Society, not by Klebs. Dr. Fulton was the compiler, but the work was principally done by Louise Eisenhardt and Miss Madeline Stanton, Dr. Cushing's former secretary. 